\title{
THE CHALLENGES OF DIPLOMATIC PRACTICE IN AFRICA
}

\author{
John Akokpari ${ }^{1}$
}

\begin{abstract}
Diplomacy has been used in the conduct of foreign policies in Africa. However, a disconcerting trend in the practice of diplomacy in Africa is the often limited successes, and sometimes failures, of states and regional organisations in achieving foreign policy objectives. Remarkably, such failures are not only typical of diplomacy targeting external actors, but are equally visible in intra-African diplomacy. By and large the diplomatic skills of Africa are tested mostly during periods of conflicts and threats to regional security. In most of these situations, diplomacy has proved to be ineffective in achieving desired outcomes. Consequently, most conflicts remain unresolved, while threats to good governance persist. The failures of diplomacy are largely due to a confluence of factors, including the quality of diplomacy and mediators, the pervasiveness of conflicts, Africa's lack of international influence, its dependence on external actors and consequent lack of assertiveness, as well as Africa's lack of courage to stand up to errant leaders whose actions threaten good governance and regional security.
\end{abstract}

Keywords: Africa; diplomacy; foreign policy; conflicts; mediators; African leaders; military intervention.

Sleutelwoorde: Afrika; diplomasie; buitelandse beleid; konflikte; bemiddelaars; Afrika-leiers; militêre intervensie.

\section{INTRODUCTION}

A visible trend in Africa is the frequent failure of foreign policy to achieve desired objectives. While this feature is palpable among states, it is also evident in the politics of sub-regional and continental organisations. The diplomatic efforts of the African Union (AU) have seen limited successes on some major regional and international issues, forcing it to bow to the dictates of external actors. Generally, the efficacy of Africa's diplomatic practice is tested in conflict situations, where there is expectation on states and regional bodies to contain, terminate or manage them. The bulk of evidence suggests that, with a few exceptions, including the uneasy peace installed in Zimbabwe in 2008 by mediators from the Southern African Development Community (SADC), the successful termination of the Liberian and Sierra Leonean conflicts, diplomacy has in recent years failed in mitigating various threats to security. In the Ivory Coast and Libyan conflicts in 2010 and 2011

1 Associate Professor, Department of Political Studies, University of Cape Town.

E-mail: john.akokpari@uct.ac.za 
respectively, for example, the limitations of the Economic Community of West African States (ECOWAS) and the AU to muscle diplomatic power to resolve the conflicts were pathetically exposed. In these two conflict situations, it required the involvement of France and the North Atlantic Treaty Organisation (NATO) respectively, to end these conflicts. At the state level, both the Nigerian government and ECOWAS appear incapable of mitigating the seemingly intractable insurgency of Boko Haram, while South Africa and the SADC seemed to have given up on efforts to instigate democratic reforms in the Kingdom of Swaziland. Africa's lack of diplomatic clout on the global stage is even more palpable, leaving the continent both pliable and vulnerable to pressures from external actors.

This article highlights the causes of the limited successes, often failures, of diplomacy in Africa. It argues that the critical instruments required to enhance the chances of attaining diplomatic success are in short supply. This deficit has been exacerbated by the proliferation of factors, including the ubiquity of conflicts and violence, Africa's pliability and vulnerability in the international system, the absence of strong and assertive leaders, and diplomatic mechanisms. These deficits lead to ephemeral diplomatic outcomes. The article has subsections, with the next section providing some conceptual clarity on foreign policy and diplomacy. Thereafter, a general discussion on the importance of diplomacy is undertaken, which is followed by a discussion on trends in diplomatic practice in Africa. The subsequent section highlights some of the main sources of diplomatic failures, while the conclusion summarises the key arguments in the article.

\section{EXPLAINING DIPLOMACY}

Diplomacy and foreign policy are often conflated, mainly because both terms describe the interaction between actors in the international system (Akokpari 2005). Diplomacy is generally used with the aim of achieving specific objectives and it is often explained in relation to foreign policy. The term "foreign" depicts the policy as targeting actors beyond the borders of the territorial state. While foreign policy exclusively describes interactions beyond the state, diplomacy may apply in both international and domestic environments. In the African context, therefore, diplomacy may include interaction between the state and actors both within and outside its borders. A state aiming to end insurgency within its territorial borders requires diplomacy to conduct negotiations. Similarly, the resolution of conflict between two warring constituencies within a state requires the use of diplomacy. As a general rule, foreign policy, like diplomacy, is aimed at achieving specific objectives (Hermann 1990). Thus, to place the concept of diplomacy in perspective, it is expedient to explain foreign policy, even if cursorily. While a generally agreed definition of foreign policy is elusive (Cohen and Harris 1975:318), this article 
adopts the conceptualisation of Holsti (1995:83), who depicts it as a set of, "ideas or actions designed by policy makers to solve a problem or promote some change in the policies, attitudes or actions of other states, in non-state actors (e.g. terrorist groups) in the international economy or in the physical environment of the world".

However, some observers have sought to demonstrate a link between domestic and foreign policy. This thinking suggests that foreign policy is the "extension abroad of domestic policy" (Pym 1982). The accuracy in this thinking is vividly demonstrated in the determination of Western states to export liberal values democracy, good governance, respect for the rule of law and competitive multiparty election - by using these as conditions for aid and investment. Consistent with realist tendencies, policy makers aim to use foreign policy to influence events and outcomes to their advantage. Foreign policy is pursued using the instrument of diplomacy, as Paul Gore-Brooth (1974:15), a former British diplomat, aptly puts it, "foreign policy is what you do, diplomacy is how you do it".

Put in historical perspective, diplomacy is an old practice, which predates the state and the Westphalia Treaty (Nanjira 2010:134). However, it became more refined and institutionalised in the post-Westphalian era when states established formal relations with each other (White 2001:318). Yet, diplomacy remains a nebulous term, lacking consensus on its conceptualisation and often defined in self-serving terms. This lack of consensus results from at least two reasons: firstly there is an increased number of actors - state and especially non-state - using diplomacy in the conduct of their international relations; and secondly, there is a growing number of issues (conflicts, disagreements, and trade negotiations) whose resolution requires the use of some form of diplomacy. Some observers have tried to navigate this difficulty by distinguishing between macro and micro diplomacy. The former refers to diplomacy on the global stage, while the latter, more confined in scope and often bilateral in nature, is the diplomacy relating to states (White 2001:318). What then is diplomacy? The term has conventionally been used in the implementation of state policies. Thus, in his discussion of statecraft, David Baldwin (1985:13) defined diplomacy as "influence attempts relying primarily on negotiations". Thus, in simplistic terms, diplomacy is taken to mean the process of conducting or managing the domestic and foreign policies of states and nonstate actors.

Diplomacy takes various forms, the most popular of which is negotiations. Indeed, some observers define and, indeed, synonymise diplomacy with negotiations, especially when the effort is towards the resolution of a conflict. According to Brian White (2001:318), diplomacy is, "a communications process between international actors that seeks through negotiation to resolve conflict short of war". Negotiations thus remain central to most diplomatic overtures. Other forms of diplomacy include bargaining (Holsti 1982:159) and various non-coercive approaches to resolving 
disputes. White (2001:138) refers to the mode of diplomacy involving non-coercive instruments as "pure diplomacy". This is contrasted with "mixed diplomacy" that combines both coercive and non-coercive methods. The conventional perception of diplomacy is that it involves mechanisms that exclude the use of force. However, there is a school of thought that conceives diplomacy in terms of the use of force. Carl von Clausewitz, a former Prussian military general, opines that force is a legitimate form of diplomacy. In his famous treatise On war, Clausewitz (1873:1) depicts war as, "politics by other means [...] an act of violence to compel our opponent to fulfil our will".

The depiction, if not acceptance, of war as a legitimate instrument of diplomacy is consistent with the philosophical stance of the dominant military powers of today - the United States of America (US) and Russia - who frequently resort to the use of military force in the pursuit of certain foreign policies. For example, in a bid to topple regimes considered errant, the US, along with the United Kingdom (UK), has used military force to effect regime changes in Afghanistan and Iraq in 2001 and 2003 respectively. Middle powers and less influential states on the other hand, traditionally tend to shy away from using military force as a form of diplomacy. Small and weak states generally prefer negotiations and multilateral approaches as conduits for their foreign policies. Some of the popular instruments of pure diplomacy include the use of special envoys, joint commissions, technical experts, persuasion (involving the use of carrots and sticks), and subversions. Other times, force is used and may take the form of overt or covert military action. The former is direct military action and includes invasion, while the latter takes the form of subversion and sabotage, assistance to rebels or the use of proxies. The conduct of diplomacy may be bilateral or multilateral; secret (quiet) or open; while at other times mediators may opt for either round table or shuttle diplomacy, depending on the conditions under which negotiations are conducted. The central question is: how has diplomacy fared in Africa - has it been effective? This is the question the following section seeks to address.

\section{THE PRACTICE OF DIPLOMACY IN AFRICA}

\subsection{Conflict resolution}

Conflicts are common in Africa and provide the greatest test to the efficacy of diplomatic practice on the continent. Generally, mediators from regional bodies and the AU have been used as the first step in resolving conflicts. In most of the conflicts in the Central African region and in the Great Lakes region, the AU has been the principal mediator, although on a few occasions Kenya and Tanzania led mediation efforts in the region. Generally, the Central African region lacks a "leader" who is both capable and willing to bear the costs of peace in that region. Cameroon, the 
largest economy in the Central African region should have been the "hegemon", but has shown no willingness to assume that leadership role. In West Africa, Nigeria has led ECOWAS mediation efforts in conflict resolution, evidenced by Abuja's role in the conflicts in Liberia and Sierra Leone. The exception to this was Nigeria's surprising backstage posture in the 2010 post-election conflict in the Ivory Coast. The reasons were not far-fetched; Nigeria has in the last five years been saddled with domestic security challenges posed by Boko Haram. The fight against Boko Haram has sapped a great deal of Nigeria's energies and it could not combine this with an involvement in a military campaign in the Ivory Coast (Cook 2011:18). With domestic pressure on his government to annihilate Boko Haram, President Goodluck Jonathan needed to commit the resources at the country's disposal to the fight against Boko Haram.

In Southern Africa, the mediatory role of South Africa, a regional leader, has been visible in Burundi, Zimbabwe, the Central African Republic (CAR), the Democratic Republic of Congo (DRC) and Lesotho. In Burundi, the CAR and the DRC, and in the Ivory Coast, Pretoria mediated on behalf of the AU, while it represented the SADC in its mediation efforts in Zimbabwe and Lesotho. Generally, in mediation, mediators meet with leading protagonists and attempt to get them to commit to a ceasefire through signing an agreement. In the particular case of Burundi in 2003, South Africa not only assisted in brokering peace between the warring factions, but it also helped in conducting post-conflict elections in the country (Howard 2008). South Africa and the AU are presently at the centre of efforts to restore calm to Burundi. The present crisis was triggered by President Pierre Nkurunziza's announcement in March 2015 to stand for a third term, in contravention of Burundi's Constitution. This led to protests and an unsuccessful military coup led by General Godefroid Niyombare on 13 May 2015 to topple Nkurunziza (BBC 2015). The Burundi situation remains fluid and unsettled.

\subsection{Military intervention}

Resolving conflicts through military intervention has in recent years become a popular option in Africa. Military intervention is used either to end conflicts (peace enforcement) or where a ceasefire has been achieved, to keep the peace (peacekeeping). Almost without exception, military intervention is contemplated or used where pure diplomacy has failed. Yet, during much of the 1980s, besides the Nigerian-led Organisation of African Unity (OAU) intervention in Chad, military intervention remained an exception, never the rule, for at least two reasons; firstly, the 1980s coincided with the height of the Cold War during which, assisted by proxies, the US and Russia fought Africa's wars overtly, but sometimes covertly. This provided little scope for OAU intervention in conflicts. Secondly, the principle of non-interference in the internal affairs of member states, which 
guided the working of the OAU, minimised possibilities for military intervention in countries. The Cold War years thus provided limited impetus for the use of military intervention as an instrument of diplomacy.

In the post-Cold War era, however, military intervention became popular as a diplomatic instrument in conflict management. This was necessitated by a combination of factors. Firstly, the abatement of the Cold War diminished Africa's strategic importance to the West (Schmidt 2010:17). Western governments were no longer interested in protecting beleaguered African regimes, which previously served their interests. Although Western countries remained interested in supporting Africa's peace-making and peacekeeping efforts with financial resources and logistics, they were generally loathed to commit soldiers in the resolution of Africa's conflicts. Thus, the retreat of the West and the subsequent evolution of the "African solutions to African problems", popularised by former UN SecretaryGeneral Boutros Boutros Ghali's "Agenda for Peace" (UN 1992) and a second report in 1995 (UN 1995), meant Africa was left with no option but to adopt military intervention as a key instrument of diplomacy in conflicts. Secondly, the AU, which was inaugurated in July 2002, embraced the idea of "non-indifference"; thus making a radical shift from the passive posture of the OAU to conflicts. Article 4(h) of the Constitutive Act of the AU mandates the Union to intervene in countries in respect of "grave circumstances [of] war crimes, genocide and crimes against humanity" (Witt 2013:16). Thirdly, the International Commission on Intervention and State Sovereignty's (ICISS) report, "Responsibility to Protect (R2P)", published earlier in 2001 gave a further impetus for intervention. R2P obligated member states of the UN to defend citizens if their governments appear incapable of protecting them or if the state is the source of the citizens' insecurity (Sarkin 2008:57). The principle of humanitarian intervention has thus given further justification for military interference.

As far as conflict resolution in Africa is concerned, the dominant paradigm of diplomacy at present appears to be the use of military force. This is borne out by the legion of examples of military interventions in Africa's conflicts. In 2010, the postelection conflict in the Ivory Coast ended only with the use of France-supported ECOWAS forces (Mail online 2011). Similarly, French military support to the AU led to the repulsion of Tuareg rebels in Northern Mali in January 2013 after ECOWAS non-military diplomacy yielded little dividends (Haysom 2014:4). Further, following the 2003 escalation of conflict between the Sudan Liberation Movement Army (SLM/A) and the Justice and Equality Movement (JEM) on the one hand, and government-sponsored Janjaweed on the other, the AU responded with the deployment of the AU Mission in Sudan (AMIS) force in 2004. However, overstretched and ill-equipped to contain the conflict, a hybrid force of $\mathrm{AU}$ and UN soldiers - United Nations and African Union in Darfur (UNAMID) - was 
deployed in Darfur in 2007 to contain the conflict (United Nations 2007). After various mediation attempts failed to restore peace in troubled Somalia, the AU deployed a full military offensive against Somali insurgents, especially al-Shabaab, using the AU Mission in Somalia (AMISOM) in 2007. AMISOM was bolstered by the large contingent of Kenyan troops which entered Somalia in October 2011, following an upsurge of al-Shaabab-perpetrated terrorist attacks in the north eastern and coastal parts of the country against foreign aid workers and tourists respectively (The Guardian 2011). Also, in both the DRC and CAR, where conflict has threatened to spin out of control, the key regional response, after mediation had failed, has been the military option.

\section{THE FAILURE OF DIPLOMACY IN AFRICA: CAUSES}

Although the use of military force as an instrument of diplomacy has been effective in ending conflicts in Liberia, Sierra Leone, the Ivory Coast and Burundi, it has failed to restore peace and security in several other conflict areas. The AU failed to resolve the Libyan conflict in 2011, Somalia has not known peace for over two decades, and conflict continues to rage in Eastern DRC and in Northern Nigeria, where Boko Haram, the militant Islamist group, has proved a hard nut for the Nigerian government to crack. In some cases, post-conflict peace arising out of military intervention remained fragile at best. In Liberia, the peace installed in 1997 with the election of Charles Taylor as President, after years of conflict, turned out to be tenuous and ephemeral.

Similarly, the DRC and CAR have oscillated between conflict and fragile peace during the last ten years. In Swaziland and Zimbabwe, SADC efforts at instigating reforms on governance and human rights have yielded limited outcomes, while Gambia and Togo, two small states, thwarted ECOWAS' efforts at passing a resolution to limit presidential terms to two (Darboe 2015). The AU failed to dissuade Burundian President, Pierre Nkurunziza, from standing for a third term, despite popular protests in the country and the loss of lives (Manirabarusha 2015). Diplomacy, whether pure or mixed, has not appeared to have been effective in achieving desired results in most cases in Africa. A number of related factors account for this.

\subsection{Absence of diplomatic instruments and effective mediators}

Without a doubt, a leading cause of diplomatic failures is the absence of effective instruments. While the use of military intervention remains a popular diplomatic instrument, peace-making and peacekeeping forces are often ill-equipped, underfinanced and poorly trained. In some cases, too, the forces lack the numbers required for success. In 2004, for example, the AMIS force in Darfur initially 
numbered a paltry 7000 troops but grew to 9000 by October 2007. Yet, this number of soldiers was still too small to be effective in a land area as large as Texas or Spain (Akokpari 2012a:159). This challenge has been exacerbated by the unwillingness of African states to provide troops after initially committing themselves. The inevitable consequence has been for regional organisations and the AU to rely on extra-Africa actors for funding and other forms of support. In 2011, $60 \%$ of the AU budget came from the European Union (EU), US and China (The Economist 2011), while, as noted above, ECOWAS frequently relied on France in conflict intervention. This development often exposes the myth of the muchtrumpeted "African solutions to African problems" slogan. The AU peacekeeping operations (PKOs) in the last 15 years have relied on external support. Intervention as an instrument of diplomacy is flawed, failing to address the structural causes of conflicts and typically imposing peace rather than allow contending factions to resolve long-standing issues. In the words of Adebayo Adedeji, interventions fail to "master and comprehend" the causes of conflict (Adedeji 1999:3).

In cases where mediation is used as an instrument of diplomacy, negotiators are often unskilled, lacking not only in appropriate negotiating techniques, but also naïve about the background to the conflict. It has become typical for the AU to use former heads of states as mediators, mostly with disastrous outcomes. In February 2012, for example, the AU dispatched former Nigerian president, Olusegun Obasanjo, as an envoy to mediate in the conflict in Senegal. The violence was spawned by the decision of 85-year Abdoulaye Wade to run for a third term in contravention of the country's Constitution. Mr. Obasanjo, however, boasts no track record as a successful mediator. His mediation in Zimbabwe, as an envoy of the Commonwealth Heads of States and Governments in 2003, yielded no results, while Nigeria witnessed sectarian violence that claimed hundreds of lives during his eight-year presidency between 1999 and 2007 (Akokpari 2012b:14). Obasanjo was himself a questionable democrat, who failed in a controversial bid to run for a third term in Nigeria. Expectedly, both President Wade and the opposition rejected Obasanjo's proposal for the former to be allowed to stand, but to step aside after two years if he won the polls (BBC 2012).

Similarly, former South African president, Thabo Mbeki, who served as the AU mediator in various conflicts, can only boast of mixed results as a peace envoy. Influenced by the successful, but ephemeral inclusive Government of National Unity (GNU), formed in the immediate post-apartheid years, Mbeki seems to believe that the solution to every post-election conflict in Africa lies in the formation of a GNU. As the chief SADC mediator in the Zimbabwean crisis, Mbeki advocated and indeed succeeded in engineering a GNU between President Robert Mugabe and the ZANU-PF, who lost the polls, and the opposition Movement for Democratic Change (MDC) under Morgan Tsvangirai in early 2009. It was clear though that 
the Zimbabwean GNU was never united (Noyes 2012). Inspired by the apparent success in Zimbabwe, Mbeki proposed the formation of a GNU in the Ivory Coast when he was dispatched to Abidjan as the AU envoy in the country's post-election conflict in 2010 (Martins 2011:81). However, Mbeki's idea of a unity government was rejected, not only by Alassane Ouattara, who was widely known to have won the election, but also by ECOWAS, which feared it would encourage sitting presidents who lose elections to continue in office through unity governments. In opting for such short-cuts, which in most cases were temporal solutions, Mbeki was shying away from confronting the truth and condemning the loser.

A disturbing feature of Mbeki's diplomacy has been his preference for short-cut approaches to conflict resolution, underscored by a willingness to empathise with, even protect, errant leaders in the name of "African solidarity, anti-imperialism and old-style sovereignty" (Geldenhuys 2010:166). In 2008, he advocated for the withdrawal of war crime charges against Sudanese president, Omar al-Bashir, on grounds that the indictment would complicate peace efforts in Darfur (Sudan Tribune 2009). Seeking a shortcut approach, the AU instigated a GNU in Kenya following violence in the aftermath of the presidential polls in 2007 (Mapuva 2013: 105). Endemic mutual suspicion, fragility and ephemerality underscore the bankruptcy of unity governments as diplomatic options in postconflict situations.

\subsection{Persistence of conflicts}

The persistence of conflicts further compromises the credibility of Africa's diplomacy. Africa remains a leading theatre of conflicts, recording the highest number globally during the last 20 years. Africa's conflicts have since the 1960s been estimated to have claimed 10 million lives and cost the continent over US\$250 billion (Murithi 2005:82). By the beginning of 2014 no fewer than six African countries, including the CAR, DRC, Libya, Mali, Nigeria and Somalia, were experiencing full-scale conflict (Shah 2014). Since the beginning of 2010, the UN has had close to 20000 peacekeepers in the DRC, representing the largest contingent in the world. The prevalence of conflicts present challenges to diplomacy. The determination to resolve multiple, some intractable, conflicts at the same time stretches the diplomatic resources of regional organisations and the AU. The need to assemble peacekeepers for deployment into conflict zones, garner resources and logistics, place massive constraints on the already overstretched resources of the AU. Historically, the AU has struggled to timeously assemble a force for dispatch to areas of conflict. It is even more difficult to find peacekeepers for two or three conflicts raging simultaneously. In turn, such constraints may lead to either the fashioning of half-baked solutions to protracted conflicts, or the prioritisation of one conflict over the other. In 2011, the Ivory Coast's post-election 
conflict was unfolding almost at the same time as the crisis in Libya, seriously dividing the attention of the AU. In this instance the AU focused on the Libyan conflict, leaving the Ivory Coast to ECOWAS.

\subsection{Lack of influence in the international system}

Africa remains a vulnerable continent, lacking political and economic influence in the international system. Accordingly, it has limited diplomatic options when dealing with actors within, and especially external to the continent. Within the continent, sanctions or threats of sanctions do not serve as sufficient impulses to cause changes in the policies of errant states. Delinquent countries hardly take regional and AU threats seriously. Threats to suspend Zimbabwe from the SADC and the AU failed to induce political reforms. Robert Mugabe and ZANU-PF continued with their oppressive policies until the SADC thought it better to keep Zimbabwe in the community, than to exclude it. In a defiant mood Mugabe organised the 2013 Zimbabwe national elections on his terms, defying guidelines set out by the SADC (Fabricius 2013). Similarly, the SADC's resolutions on the Madagascar crisis were only partially implemented. Madagascar was suspended from the SADC and the AU, following the military coup in March 2009 that toppled elected president Marc Ravalomanana and installed the military-backed mayor of Antananarivo, Andry Rajoelina, as president. Notwithstanding the suspension, Rajoelina continued to defy SADC directives, including its recommendation to allow the return of self-exiled Ravalomanana into the country (Fabricius 2013).

The tendency of African leaders to empathise, rather than criticise culpable peers has not helped the outcome of diplomatic efforts. The AU has so far not mastered the courage to chastise African leaders who clearly threaten the security of their citizens or pursue policies that can potentially generate conflict. On the contrary, the AU has appeared to accommodate and, in fact, side with such leaders. For example, in 2007, African leaders threatened to boycott the Euro-African Summit in Lisbon, Portugal, following the EU decision to exclude Robert Mugabe, who was under EU travel ban. The ban was imposed on the Zimbabwean leader and his top government officials in 2002 for presiding over grotesque human rights abuses in his country (The Guardian 2015). The collective threat by African leaders to boycott compelled the EU to allow Mugabe into the summit. Curiously, at the height of the Zimbabwean crisis, neither the SADC nor the AU officially criticised Mugabe for his human rights abuses. Only the leaders of Botswana and Zambia openly condemned Mugabe for his brutal repression of opponents. In a SADC summit in 2007, former president Levi Mwanawasa of Zambia accused Mugabe of turning his country into a "sinking Titanic" and bemoaned African leaders' silence on Zimbabwe (The Telegraph 2008). Similarly, the SADC has been silent on the crackdown on opponents and the restriction of political space in the Kingdom of 
Swaziland. The failure to stand up to errant leaders has helped to seriously diminish the impact of diplomacy on these countries.

Yet, Africa's lack of influence is even more apparent in its interactions with external actors. Africa is generally weak and pliable and dances to the music of external actors. Consequently, it has weak bargaining power vis-à-vis external actors. The price of primary commodities, the chief export of most African countries, is determined not by Africa, but by actors external to the continent. The signing of the Economic Partnership Agreement (EPAs) with the EU in 2014 by nearly all sub-Saharan Africa countries typifies Africa's lack of bargaining power. In their current design EPAs not only balkanise Africa further, but they also compel the continent to liberalise its market to make it easily accessible to Europe (Mutume 2008). In fact, concerns with EPAs relate to their tendency to undermine industrialisation and consequently compound the already grave unemployment crisis in Africa (Bridges Africa 2014a). With such clear knowledge of the potential harm of EPAs, the AU sanctioned the signing of the agreement. Even more remarkable, the EU imposed arbitrary deadlines for the conclusion of the negotiations without regard to the objective realities on the ground. In the process of negotiation, Africa hardly presented a coordinated position on the EPAs. Rather, African states were deeply polarised over EPAs (Mutume 2008:16). While Swaziland, Botswana Mozambique and Lesotho, along with Ghana and the Ivory Coast, among others, were in compliance with the signing of interim agreements, Malawi, Namibia, and Nigeria, among others, were opposed to it. Importantly, after protracted negotiations, Africa eventually signed the EPAs, albeit reluctantly, in the form they were presented, as it lacked the clout to negotiate for a better deal.

Lacking sufficient leverage, it is unclear if Africa's non-permanent members in the UN Security Council vote objectively on the merit of issues. African members have tended to vote in ways that are consistent with the foreign policy objectives of the permanent members. In March 2011, the AU took a collective decision not to support the imposition of a "no fly zone" over Libya. A few days later, on 17 March, South Africa, along with Nigeria and Gabon, Africa's non-permanent members of the Security Council, all voted in favour of the resolution, which also called for the use of "all necessary measures" to protect civilians. Pretoria justified its support for the resolution on grounds of protecting civilians (Moore 2011). It was less surprising that Nigeria and Gabon, who are comparatively less autonomous in their foreign policies, voted along with Western countries in support of the resolution. However, it was shocking that South Africa, which has a greater capacity to follow an independent foreign policy and defend Africa's interest, contradicted the collective position of the continent. Prior to the "no fly zone" vote, Africa proposed a "Road Map to Peace" for Libya, which called for talks between Qaddafi and rebels that would lead to democratic reforms. This, however, could not persuade 
NATO and the West to abandon the clamour for regime change. The diplomacy of the AU thus failed to resolve the Libyan conflict.

\subsection{Dependence on external actors}

Africa's vulnerability and lack of influence has been exacerbated by its notorious dependence on external actors for markets, aid and investments. The continent presently relies heavily on external markets to sell agricultural commodities. According to WTO data, intra-Africa trade in 2014 stood at a paltry $12 \%$. This figure pales when compared to $60 \%$ and $30 \%$ in the EU and the Association of South East Asian Nations (ASEAN) respectively (Bridges Africa 2014b). The bulk of Africa's trade is with the EU. This has arisen from at least two interrelated factors; the first is what Thomas Callaghy (1994:241) referred to some two decades ago as the "fallacy of agricultural composition", which describes Africa's production of similar agricultural commodities. This phenomenon offers little opportunities for marketing agricultural products, mostly raw materials, on the continent. Secondly, the obvious, yet disconcerting, truism is that there are few to no industries to process the primary agricultural raw materials produced in Africa. With the exception of the few oilproducing countries, the structure of production in Africa has not seen significant diversification since independence. Most African economies still display the trappings of the colonial economy, which place an emphasis on extractive resources. The inevitable consequence is for Africa to find markets beyond the continent.

Further, Africa depends on external actors for official development assistance (ODA) to supplement its budget. Nearly all sub-Saharan African countries experience budget shortfall, sometimes on a regular basis, for which external financial assistance is required. Countries therefore rely on external bilateral and multilateral aid or credit to finance development programmes. In addition, foreign assistance is required for major capital investments - roads, railways, hospitals and mining. The $\mathrm{AU}$ is no exception; it almost constantly has to rely on the EU, China and the US for financial support to supplement its budget. China is also becoming a dominant force and sometimes a source of discomfort to Africa's industrial development. There are growing labour concerns with Chinese goods suffocating local, especially the textile and leather, industries and escalating unemployment in sub-Saharan Africa (SSA) (Akokpari 2011). In need of Chinese assistance, African governments have become powerless to reverse the situation. In the wake of China's increasing presence in, and dominance of Africa's mineral and extractive industries, Samuel Burke (2013), a CNN news correspondent, could not have been more apt when he asked, "is China buying Africa?"

In addition, Africa depends on external actors for information and technological knowledge. While science remains the driving force of growth and development in industrialised countries, it has been missing in Africa. The 
continent's universities and research institutions, which are supposed to be the primary sources of scientific knowledge, lag behind and are making minimal impact on development. Evidence of this lies in the low ranking of African universities in relation to the best in the world. For example, the 2012/2013 ranking of the world's public and private universities by the Times Higher Education based on the four core missions of universities - research, teaching, knowledge transfer and international outlook - showed that no African university ranked among the world's top 100. There was only one among the top 200 and there were just four among the world's top 400 universities, all of which were in South Africa (Otobo 2015:132). Africa thus suffers from a "deficit" of technological information. The ultimate effect of suffering multiple deficits - markets, aid, investments and technological knowledge - is to depend on external actors, which inevitably diminishes Africa's diplomatic leverage in bargaining and negotiations on the international stage.

\section{CONCLUSION}

Intra-African interactions, as well as Africa's relations with extra-African actors are managed by diplomatic engagement. However, by and large African diplomacy has been ineffective for most of the time in achieving the desired results. Much of these failures have been evident in the area of conflict resolution and in the mitigation of threats to security. Regional and continental efforts at resolving conflicts have only been partially successful.

For example, while the conflicts in Liberia, Sierra Leone and Burundi were successfully ended, those in Somalia, South Sudan and Nigeria remain seemingly intractable. In other non-combatant security-threatening situations, such as in Swaziland and Zimbabwe, where human rights are frequently abused and where the focus is on reform, African diplomacy has equally failed to instigate the desired change. The lack of diplomatic successes has been even more visible in Africa's dealing with external actors and the shortfall in African agency when it comes to managing external actors on the continent.

It is argued that the sources for the failure in diplomacy are found in a confluence of factors, including the ubiquity of conflicts, which tend to drain Africa's diplomatic resources; the lack of adequate diplomatic resources, both personnel and finance; and the continent's lack of influence in the international system, stemming largely from its pliable and dependent position in the international system, among other things. Together, these factors have vitiated Africa's ability to negotiate with both domestic and international actors with any clout. 


\section{LIST OF SOURCES}

Adebayo, A 1999. "Comprehending Africa's conflicts". In: A Adebayo (ed.), Comprehending and mastering African conflicts: The search for sustainable peace and good governance. London: Zed Books, pp. 3-21.

Akokpari, J 2005. "Ghana: Economic dependence and marginalised foreign policymaking". In: J Robertson and M East (eds), Diplomacy and developing nations: Post-Cold War foreign policy-making structures and processes. London: Routledge, pp. 181-199.

Akokpari, J 2011. "The political economy of Chinese capital in sub-Saharan Africa: implications for governance", Global Development Studies 6(3-4):49-78.

Akokpari, J 2012a. "Limited capabilities, great expectations: The African Union and regional conflict management". In: S Wolff and C Yakinthou (eds), Conflict management in divided societies: Theory and practice. London: Routledge, pp. 151-166.

Akokpari, J 2012b. "Is electoral politics a new source of human insecurity in Africa?", Afro Asian Journal of Social Sciences 3(3):1-24. Online, <http:/www. onlineresearchjournals. com/aajoss/art/86.pdf>, accessed 28 June 2015.

Baldwin, D 1985. Economic statecraft. Princeton: Princeton University Press.

BBC 2012. "Senegal election: Early results point to tight race", <http://www.bbc. co.uk/news/ world-africa-17169564>, accessed 1 March 2012.

BBC 2015. "Burundi President Nkurunziza faces attempted coup", <http://www. bbc.com/news/world-africa-32724083>, accessed 19 November 2015.

Bridges Africa 2014a. "African Trade Ministers split on EPA path forward as October deadline looms", 7 May. Online, <http:/www.ictsd.org/bridges-news/ bridges-africa/news/african-trade-ministers-split-on-epa-path-forward-as-october>, accessed 10 January 2015.

Bridges Africa 2014b. "African trade ministers split on EPA path forward as October deadline looms", 15 May. Online, <http://www.ictsd.org/bridges-news/ bridges-africa/news/african-trade-ministers-split-on-epa-path-forward-asoctober-0>, accessed 12 October 2014.

Burke, S 2013. "Is China buying Africa?”. Online, <http://amanpour.blogs.cnn. com/2013/ 03/29/is-china-buying-up-africa/>, accessed 10 June 2015. 
Callaghy, T 1994. "Civil society, democratisation and economic change: A dissenting opinion about resurgent societies". In: J Harbeson, D Rothchild and N Chazan (eds), Civil society and the state in Africa. Boulder: Lynne Rienner, pp. 257-319.

Cohen, B and H Scott 1975. "Foreign policy". In: FI Greenstein and N Polsby (eds), Handbook of Political Science. Vol. 6: Policies and policy making. Reading, MA: Addision Wesley, pp. 381-438.

Clausewitz, C 1837. On war. Translated by JJ Graham. London: N Trubner.

Cook, N 2011. Cote d'Ivoire's post-election crisis. Congressional Research Service. Online, <www.crs.gov>, accessed 12 July 2015.

Darboe, M 2015. "Ecowas suspension of term limit bid saddening", The Standard, 1 June. Online, <http://standard.gm/site/news/7181-Ecowas-suspension-term-limitbid-saddening. html $>$, accessed 10 June 2015.

Fabricius, P 2013. "SADC must treat Zimbabwe as firmly as it is apparently planning to treat Madagascar". Online, <http://www.issafrica.org/iss-today/sadcmust-treat-zimbabwe-as-firmly-as-it-is-apparently-planning-to-treat-madagascar>, accessed 1 July 2015.

Geldenhuys, D 2010. "South Africa: The idea-driven foreign policy of a regional power". In: D Flemes (ed.), Regional leadership in the global system: Ideas, interests and strategies. Surrey: Ashgate, pp. 151-168.

Gore-Brooth, P 1974. With great truth and respect. London: Constable.

Haysom, S 2014. Security and humanitarian crisis in Mali: The role of regional organisations. London: Overseas Development Institute.

Hermann, C 1990. "Changing course: When governments choose to redirect foreign policy”, International Studies Quarterly 34(1):3-21. http://dx.doi.org/10.2307/2600403

Holsti, KJ 1982. "Bargaining theory and diplomatic reality: The Conference on Security Cooperation in Europe (CSCE) negotiations", Review of International Studies 8(3):159-170. http://dx.doi.org/10.1017/S0260210500115578

Holsti, KJ 1995. International politics: A framework of analysis. $7^{\text {th }}$ ed., Englewood Cliff: Prentice Hall.

Howard, LM 2008. UN peacekeeping in civil wars. New York: Cambridge University Press. 
Mail online 2011. "Gbagbo at bay: Defiant Ivory Coast dictator arrested and handed to elected leader", 12 April. Online, <http://www.dailymail.co.uk/news/ article-1375722/Ivory-Coast-dictator-Laurent-Gbagbo-arrested-handed-AlassaneOuattara.html>, accessed 10 June 2015.

Manirabarusha, C 2015. "Vice-President flees Burundi, 100 students taking refuge at U.S. embassy", The Globe and Mail, 25 May. Online, <http://www. theglobeandmail.com/news/world/vice-president-flees-burundi-100-studentstaking-refuge-at-us-embassy/article 25112659/>, accessed 10 June 2015.

Mapuva, J 2013. "Governments of National Unity (GNUs) and the preponderance of the incumbency: Case of Kenya and Zimbabwe", International Journal of Political Science and Development 1(3):105-116.

Martins, V 2011. "The Cote d'Ivoire crisis in retrospect", Portuguese Journal of International Affairs 5, Spring:72-84.

Moore, C 2011. "South Africa's about-turn on Libya: Is speaking with the AU/ BRIC majority defending the indefensible?". Online, <http://blogs.lse.ac.uk/ ideas $/ 2011 / 07 /$ south-africa $\%$ E2\%80\%99s-about-turn-on-libya-is-speaking-withthe-aubric-majority-defending-the-indefensible/>, accessed 20 June 2015.

Murithi, T 2005. The African Union: Pan-Africanism, peacebuilding and development. Burlington: Ashgate.

Mutume, G 2008. "New trade pacts threaten regional unity", Africa Renewal 22(3), October:16-17.

Nanjira, DD 2010. African foreign policy and diplomacy from antiquity to the 21st century. Westport: Greenwood Publishers.

Noyes, A 2012. “Zimbabwe's unsavory path to peace”, New York Times, 14 January. Online, <http://www.nytimes.com/2012/01/14/opinion/zimbabwes-unsavory-pathto-peace.html?_r=3\&ref=opinion>, accessed 20 June 2015.

Otobo, E 2015. "African countries: Three deficits and three futures". In: A Sawyer, A Jerome and E Otobo (eds), Africa development in the 21 st century: Adebayo Adedeji's theories and contributions. New Jersey: Africa World Press, pp. 117-138.

Pym, F 1982. "British foreign policy: Constraints and opportunities", International Affairs 59(1):1-6. http://dx.doi.org/10.2307/2620153

Sarkin, J 2008. "Humanitarian intervention and the responsibility to protect in Africa". In: J Akokpari and D Zimbler (eds), Africa's human rights architecture. Aukland Park: Jacana Media, pp. 45-67. 
Schmidt, S 2010. "Through the lens of European integration theory: African peace and security architecture as a framework in transition". In: H Besada (ed.), Crafting an African security architecture: Addressing regional peace and conflict in the $21^{\text {st }}$ century. Surrey: Ashgate Publishing Limited, pp.15-36.

Shah, A 2014. "Conflicts in Africa". Online, <http://www.globalissues.org/issue/83/ conflicts-in-africa>, accessed 10 June 2015.

Sudan Tribune 2009. "African Union Panel on Darfur postpones visit to Sudan", 29 March. Online, <http://www.sudantribune.com/spip.php?page=imprimable\&id article $=30676>$, accessed 29 June 2015 .

The Economist 2011. "The African Union short of cash and teeth", 27 January. Online, <http://www.economist.com/node/18014076>, accessed 10 May 2015.

The Guardian 2011. "Kenyan troops move into Somalia", 16 October. Online, $<$ http://www.theguardian.com/world/2011/oct/16/kenyan-troops-somaliakidnappings $>$, accessed 17 June 2015.

The Guardian 2015. "EU relaxes Mugabe travel ban", 3 February. Online, $<\mathrm{http}: / /$ www.theguardian.com/world/2015/feb/03/eu-relaxes-mugabe-travel-ban>, accessed 10 June 2015.

The Telegraph 2008. "Levy Mwanawasa: President of Zambia who stood out among African leaders in his condemnation of the regime of Robert Mugabe", 19 August. Online, <http://www.telegraph.co.uk/news/obituaries/2586928/LevyMwanawasa.html>, accessed 15 June 2015.

United Nations 1992. An agenda for peace. New York: United Nations.

United Nations 1995. Improving preparedness for conflict prevention and peacekeeping in Africa. Online, <http://dag.un.org/bitstream/handle/11176/43547/ A_50_711-EN.pdf? sequence=3\&isAllowed=y>, accessed 10 April 2015.

United Nations 2007. Sudan accepts hybrid United Nations-African Union peacekeeping force in Darfur. Online, <www.un.org/apps/news/story.asp?NewsID=22881>, accessed 2 April 2014.

White, B 2001. "Diplomacy". In: J Baylis and S Smith (eds), The globalisation of world politics: An introduction to international relations. $2^{\text {nd }}$ ed., New York: Oxford University Press, pp. 317-330.

Witt, A 2013. "The African Union and contested political order(s)". In: U Engel and JG Porto (eds), Towards an African peace and security regime. Surrey: Ashgate Publishing Limited, pp. 11-30. 